\title{
ICOM \\ Rapid reaction: ethnographic insights into the Science Media Center and its response to the COVID-19 outbreak
}

\section{Irene Broer}

\begin{abstract}
This paper offers an ethnographic account of the editorial response to the COVID-19 outbreak by the Science Media Center Germany. Ethnographic research data was gathered during a 4-week fieldstay in January 2020 which coincided with the first weeks of the COVID-19 outbreak. The findings offer insights into how the editorial staff grappled with the scientific non-knowledge and uncertainty that marked the initial phase of the global COVID-19 outbreak, while simultaneously dealing with acute journalistic demands for expertise.
\end{abstract}

Keywords

DOI

Introduction
Science and media

https://doi.org/10.22323/2.19050208

Submitted: 30th June 2020

Accepted: 27th August 2020

Published: 30th September 2020

At the time of writing, the COVID-19 pandemic has developed into a global, historic event with far-reaching consequences connecting the social world in some ways and dividing it in others. Difficult as it may be to imagine while in the thick of it, it has been only a few months since the novel coronavirus began dominating the public agenda. Its transformation from a mysterious lung disease in the Chinese city of Wuhan to a viral reality, disrupting everything from family life to international politics, took place in a matter of weeks. Central to this development has been a process of knowledge sharing between scientists, citizens, health practitioners, journalists and politicians the world over. How these communicative relationships came to be established and how the production, sharing and contestation of knowledge about the novel coronavirus took place over time are only some of the topics bound to occupy communication scholars in the future. This paper addresses these questions on a smaller scale by offering an ethnographic account of the editorial response to the COVID-19 outbreak by the newsroom staff of the Science Media Center Germany.

Science Media Centers (SMCs) are intermediary, editorial organizations that operate between the fields of science and journalism by providing journalists with summaries and expert statements on new scientific publications and science topics 
that feature heavily in the public debate. So far, SMCs have been established in the U.K., Australia, New Zealand, Canada, Japan, Germany and Taiwan. Despite their potentially high impact on the way that scientific themes and expertise are portrayed in journalism [see i.e. Williams and Gajevic, 2013; Callaway, 2013; or Rödder, 2014], SMCs have so far received little empirical investigation [Rödder, 2015; Rödder, 2020]. In an effort to close this gap, a newsroom ethnography was planned at SMC Germany as part of a larger project investigating SMCs as intermediary actors in science communication. The purpose of this qualitative approach was to gain in-depth insights into editorial processes like news gathering, expertise finding, topic selection, decision making and content production, as well as employee perspectives on the organization's role and mission. Incidentally, the month-long fieldstay in January 2020 coincided with the first weeks of the COVID-19 outbreak as it spread from China to other parts of the world, including Germany. The ethnographer's presence at SMC Germany at this time offered unique insights into how the editorial staff grappled with the scientific uncertainties surrounding COVID-19 and the rapidly rising pressure to communicate timely and conclusive scientific expertise at the same time. The ethnographic data includes interviews with newsroom staff, field notes of editorial meetings and in-office chat logs gathered in January 2020, as well as SMC publications until May 2020. In this way, this paper not only provides first-ever empirical insights into the routines and editorial practices of an SMC newsroom, but in particular offers a first-hand account of SMC Germany's response to the initial phase of the COVID-19 outbreak.

After a short exploration of the concept of Science Media Centers and their potential significance as knowledge brokers in science communication, the paper explores its main interests regarding SMC Germany's response to the COVID-19 outbreak, namely how the editorial staff dealt with the scientific unknowns and uncertainties that marked the initial phase of the global COVID-19 outbreak, while simultaneously responding to acute journalistic demands for expertise. As this paper will demonstrate, this process was marked by the gradual recognition of the outbreak as a public crisis, an adaptation of editorial routines, practices and formats and a consolidation of the organization's self-perceived mission.

Conceptual framework
In order to better understand the subject of this paper - SMC Germany - it is necessary to address its conceptual history. The origin of Science Media Centers lies in the United Kingdom, where news media have been repeatedly criticised for highlighting public concerns about several controversial scientific topics, including human-animal hybrids and genetically-modified crops [Williams and Gajevic, 2013; Callaway, 2013]. In line with the so-called "knowledge deficit model" leading science policies in the 1980s and 1990s, British academic and government elites called for increased efforts to improve the public image of science and research, for example, through a more favorable depiction in the news media [see i.e. the 'Public Understanding of Science' report published by the British Council of the Royal Society, 1986]. In this effort, the world's first SMC was founded in 2002 as a self-described "press office for science" working to unify and increase the presence of scientific voices in the media and public debate [Fox, 2009; Rödder, 2014]. To achieve this, the organization was to provide a "science news service" for accredited journalists, focusing both on agenda setting and framing of science topics in the news media [Rödder, 2020]. The main activities of the SMC would be 
maintaining an academic expert database, and providing elite journalists with summaries and expert commentary on both, new scientific publications as well as controversial science topics in the public debate. Several formats, such as fact sheets, rapid reactions as well as press briefings were created for this. Support came from the Royal Institution and later the Wellcome Trust, which is responsible for up to 30 percent of the organization's funding [Science Media Centre U.K., 2020]. The rest of its funding depends on donations by corporations, research institutes, professional societies and private individuals. To secure editorial independence, none of the sponsors are to contribute more than 5 percent of the total budget. Despite this, SMC U.K.'s corporate funding has been a source of criticism, particularly regarding alleged editorial steering from players in the biotech industry [Callaway, 2013; McKie, 2002].

Since the foundation of SMC U.K., six other independently operating SMCs have been established internationally, e.g. in Australia (est. 2005), New Zealand (est. 2008), Canada (est. 2010), Japan (est. 2010), Germany (est. 2016) and Taiwan (est. 2017). While all SMCs share many similarities, several differences may be observed. Taking the focus of this paper as an example, SMC Germany was, for instance, not initiated by politics or academia, but by the field of journalism itself. In an effort to improve journalistic accessibility to scientific expertise, Germany's association of science journalists (WPK) surveyed media professionals and academics about their stance on and criteria for a possible SMC [Rödder, 2014; Rödder, 2015]. This resulted in a proposal for an adapted SMC catering to the needs of journalism rather than the demands of science in an effort to diverge from the British "press office for science" model which could be interpreted as mouthpiece journalism [Hettwer, Rödder and Zotta, 2012]. Since 2016, SMC Germany has been operating from the WPK building in Cologne, with a team of science journalists organized along typical newsroom hierarchies. The operational funding of SMC Germany is secured by the Klaus Tschira Foundation, and, although private donations are accepted, it is not as reliant on corporate contributions as its U.K. counterpart [Science Media Center Germany, 2020]. The main activities of SMC Germany are based on those of SMC U.K., though adjusted to the German-language context. They include building a database of experts in various fields of science, creating annotated fact sheets on complex scientific topics, summarizing embargoed scientific studies, collecting expert statements, and organizing live press briefings. Due to SMC Germany's location in Cologne and the decentralised nature of German journalism, press briefings are held only a few times per year as opposed to the frequent press events hosted by SMC U.K. Finally, SMC Germany also accredits freelance and part-time journalists, not just elite journalists, to receive its content, who may use it freely and without referencing the SMC as its source. These key differences might signal that, depending on their foundational goals, editorial makeup and surrounding media environments, the international SMCs might fulfill distinct intermediary roles in between science and journalism.

Depending on theoretical disposition, there are a number of ways to describe intermediary organizations like SMCs that do not comfortably fit one field or another, yet maintain communicative ties with seemingly dissimilar actors - such as those in science and journalism. In system theory, actors located on the fringes of organizations or systems, and that function as contact points have been conceptualized as "boundary spanning units" [Luhmann, 1999; Rödder, 2012]. A recent publication described SMCs in particular as "organized contact systems" 
specifically aimed at facilitating communication between science and journalism [Rödder, 2020]. Communication scholars, on the other hand, would likely use the "gatekeeping" concept to describe the process of selecting and channeling information to a wider audience, which would then allow organizations like SMCs to be described as "network gatekeepers" in science communication [Barzilai-Nahon, 2008, p. 1497]. But also the concept of "communities of practice" based on knowledge domains and practice-based learning [Lave and Wenger, 1991] provides an interesting perspective on intermediaries that communicate between actors with different goals, needs, values and practices.

Another, perhaps more fitting description of SMCs, as this paper argues, is the concept of knowledge brokers. These can be described as intermediary actors that specifically aim to navigate the relation between producers and users of knowledge by identifying particular knowledge needs, sourcing the required expertise and making that knowledge available - usually through some means of translation [Sverrisson, 2001; Pielke, 2007; Meyer, 2010]. The concept of knowledge brokerage has been explored in relation to a wide variety of fields and situations in which efforts are made to bridge a perceived knowledge gap, for instance in business management [Hargadon, 1998; Johri, 2008], information technology [Pawlowski, Robey and Raven, 2000], public health [Satterfield et al., 2002], public policy [Ward, House and Hamer, 2009] and science communication [Wachelder, 2003; Lomas, 2007; Bielak et al., 2008]. Some authors have proposed that (science) journalists can be seen as knowledge brokers, due to their ability to translate complex information for various audiences [Patterson, 2013; Nisbet and Fahy, 2015; Donsbach, 2014; Gesualdo, Weber and Yanovitzky, 2020]. One of the main characteristics of knowledge brokers, however, is their flexibility: in order to assess knowledge needs, gather expertise, translate and disseminate knowledge, they must be able to adapt to the norms and codes of the fields they mediate between, while simultaneously remaining independent enough to resist these limitations when necessary [Shinn and Joerges, 2002; Hargadon, 2002, p. 77]. In other words: "Knowledge brokers produce, enable, and facilitate movement, and they themselves are in movement. They move back and forth between different social worlds" [Meyer, 2010, p. 123]. Therefore, while journalists may perform some elements of knowledge brokering, they are typically firmly rooted within their own field with clearly set professional norms, values and expectations. An intermediary organization like the SMC, on the other hand, constantly needs to adapt its practices to the demands of other actors to fulfill its organizational goals: determining the acute knowledge needs of journalists, gathering the necessary expertise from scientists and academic publishers, and processing this into usable formats for journalistic coverage. As shall become evident in this paper, maintaining flexible relations to all actors involved is, in fact, crucial to the functioning of SMCs, as they need to constantly oscillate between different fields in order to adequately react to the demands of particular situations.

Though much has been written about SMCs and their potential benefits and drawbacks for science journalism [e.g. Haran, 2012; Rödder, 2014; Rödder, 2015; Rödder, 2017] only few empirical studies on their inner workings or external impact exist. Those that have been conducted show that SMCs can have a significant agenda-setting and framing impact on science journalism, for example on the coverage of human-animal-hybrid experiments and genetically modified crops in the British press [Williams and Gajevic, 2013; Callaway, 2013], or on the 
coverage of the Fukushima power plant disaster in Japan [Tanaka, 2015]. While the impact of SMC Germany is still in the process of being quantitatively assessed by a small number of (student) researchers [e.g. Halbach, Forthcoming], considering the more than 800 journalists that are currently accredited, we may assume that SMC Germany is taking up a central position in German science journalism as well.

In this regard, insights into how SMCs exercise their role during public crises and times of uncertainty, such as the COVID-19 pandemic, may be of particular interest. In an effort to empirically address this, this paper uses ethnographic data gathered at the SMC Germany newsroom in January 2020 to explore the following research question: "How did SMC Germany respond to the initial phase of the COVID-19 outbreak?" In addition to providing empirical insights into editorial routines and practices, and thereby addressing the research gap on SMCs, the analysis of the ethnographic data particularly focuses on how the newsroom staff grappled with the scientific non-knowledge and uncertainty that marked the initial phase of the outbreak, while simultaneously dealing with acute journalistic demands for expertise. Crucial to the SMC's response, as will be demonstrated, was the gradual recognition of the outbreak as a crisis situation, and an adaptation of editorial routines, practices and formats to respond to the particular demands of the situation. Finally, special attention is devoted to the editorial staff's understanding of the role and mission of the SMC, particularly in relation to the COVID-19 outbreak.

Most of the data used in this paper was gathered during a four-week newsroom ethnography at SMC Germany in January, 2020. The research stay was already underway when COVID-19 began to spread from China to other parts of the world, providing a unique opportunity to observe the practices of the organization as the pandemic unfolded. Newsroom ethnographies are a type of organizational ethnography: a qualitative research process in which the researcher looks for patterns of social interaction and local perspectives from within a specific, organizational setting [Neyland, 2008; Ybema et al., 2009]. Ethnographic approaches are particularly helpful when researchers are not just interested in describing practices but also in the implicit assumptions, norms, expectations and power balances that underlie "the way that things are done around here." In order to gain an embedded or "emic" perspective, ethnographers tend to be present in their field sites for extended periods of time and typically employ a range of qualitative methods, most notably participant observation and interviewing. Newsroom ethnographies, as the term would suggest, usually take place in journalistic settings with the aim of understanding how news gets made before it reaches the headlines. Since the 1970s, this approach has resulted in descriptions of journalistic routines [Tuchman, 1973; Tuchman, 1978; Schlesinger, 1978; Golding and Elliot, 1979; Fishman, 1980], editorial structures [Esser, 1998], news values [Gans, 1979; Schultz, 2007], journalistic culture [Kunelius and Ruusunoksa, 2008], the particularities of foreign correspondence [Pedelty, 1995; Hannerz, 2004], newsroom "lingo" [Cotter, 2010] and online news media [Cottle, 2000; Boczkowski, 2004; Paterson and Domingo, 2008; Paterson and Domingo, 2011].

The purpose of the newsroom ethnography at SMC Germany was to gain insight into editorial processes like news gathering, expertise finding, topic selection, decision-making and content production, as well as employee perspectives on the 
organization's role and mission. The fieldstay resulted in a large and varied dataset, including ethnographic field notes, interviews, publications and in-office chat logs, which allowed for a comprehensive and timely overview of the developments that occurred in the newsroom as the COVID-19 pandemic spread around the globe.

The ethnographer was present at SMC Germany on all working days from 6 to 31 January, 2020. Field notes and vignettes were written of twice-daily editorial meetings, observations of story pitching preparations and story production. A total of 14 interviews were held with all members of the 8-headed editorial team, including the editor-in-chief and deputy editor-in-chief. The interviews were semi-structured but allowed for flexibility to respond to key events both outside and within the newsroom. Noteworthy is that the ethnographer was also given access to the in-office chat channels that, as it turned out, became important sites for knowledge sharing and decision making. The analysis includes the content of two chat channels, one dedicated to health topics and the other to high-alert messages sent during the fieldstay period. In addition, the ethnographer received all publications that SMC Germany sent out to accredited journalists from January up to May 2020. These publications have also been included in the data for this paper, as they provide insights into how the developments observed during the research stay, e.g. new formats, thematic focus on COVID-19, progressed over the following months.

The data analysis was guided by constructivist grounded theory which, other than classical Glaserian or Straussian grounded theory, allows for the inclusion of preconceived ideas (e.g. from literature and previous experiences) as well as pre-defined research interests, so as long the researcher remains reflexive and flexible to adjust focus throughout the analysis [Charmaz, 2006; Charmaz, 2014, p. 153]. In this case, the predefined research interests included the organization's role, mission and editorial processes, but later became more focused towards editorial responses to the COVID-19 outbreak and the uncertainty and time pressure that went alongside it. As is common in constructivist grounded theory, the coding process was split into phases of initial and focused coding [Charmaz, 2006; Hunter et al., 2011]. Using MAXQDA, a team of two started by open-coding the first five interviews, allowing for only minimal interpretation. Through intercoder discussion, these initial codes were summed up into slightly more abstract codes depicting actions, processes, strategies and motivations (e.g. "planning press briefings", "consulting expert sources", "determining topic relevance", "assessing potential media impact", "wanting to support journalists", "dealing with opposing expertise" or "feeling need to react to political debates"). The next interviews were analysed using these codes alongside new open codes, after which the process of discussion and abstractification was repeated. As the outbreak of COVID-19 only really became an interview topic after the second week of the ethnography, those interviews were coded accordingly (e.g. "evaluating public relevance", "determining risk", "dealing with uncertainty", "contacting expert sources from the past" or "underscoring role or opportunity for SMC"). Secondly, the field notes were analysed using applicable codes derived from the interviews as well as codes specifically focusing on editorial routines, challenges and decision-making (e.g. "monitoring German press", "pitching a topic", "deciding for/against a topic", "discussing political debate", "weighing scientific quality", "determining need for scientific expertise in public debate"). Field notes taken during daily editorial meetings were coded specifically for COVID-19 (e.g. 
"discussing uncertainty", "updating staff on status of new virus", "gathering expertise in preparation of possible outbreak", "drawing parallels to previous epidemics", "deciding against / for coverage of virus", "deciding on best publication format", "dealing with quickly changing numbers", "designing paper ranking system"). Thirdly, the in-office chat logs were coded specifically for the thematic content (e.g. "coronavirus", "organ donation") and purpose of the messages (e.g. "sharing international news item", "sharing preprint study", "warning about false data", or "notifying staff of next steps"). Finally, the publications sent out by the SMC from January until May 2020 were coded for their themes and formats, in order to monitor how the discussions and adaptations observed during the fieldstay developed in the following months. In the final step of analysis, the four data types were triangulated by grouping all documents by date and coding for developments on a day-by-day basis. Here, the previously constructed codes on editorial considerations, decision-making processes, strategies for finding expertise and dealing with uncertainties were analyzed specifically in relation to the development of COVID-19 as a topic. The result of this iterative analytical process is an in-depth account of SMC Germany's response to the early phase of the COVID-19 outbreak.

\section{Findings}

The following paragraphs follow a chronological account of the processes and practices that were observed during the four-week ethnography at SMC Germany. The subheaders reveal some of the most important connections made during the later stages in the data analysis. In general, the everyday observations at the SMC Germany newsroom showed that most of its editorial practices are defined by a process of continuous anticipation and reaction to events within science, society and politics. These routines had a large influence on the SMC's initial response to the COVID-19 outbreak. This response was marked by a gradual process in which the editorial team constantly weighed the scientific uncertainties surrounding the virus against its public relevance. The empirical account that follows, highlights how routinized, daily practices of anticipation prepared the editorial team for a swift response, while the rapidly changing situation pushed the editorial team to adapt its routines, norms and output formats in order to fulfill its role and mission as a knowledge broker for science journalism.

\subsection{Preparation by anticipation}

Much of the work done by the editorial team is "gatewatching" [Bruns, 2005]: the process of structurally monitoring a variety of sources to identify developments in ongoing and new topics expected to receive significant media attention. To quote the deputy editor-in-chief: "Our radar screen is always turned on." Throughout the day, the editors scan the publications of news agencies, German news media, European and German political agendas and specific social media accounts for predefined key themes relevant to SMC Germany's coverage. In addition, they monitor developments in science by scanning so-called "embargo-emails" sent out by the world's largest academic publishers. These emails are intended for journalists and usually contain around 50 papers that are soon to be published in specific journals. The editorial team receives dozens of these emails per week. In addition, an automated search of the most common preprint repositories or "rXivs" flags non-peer-reviewed papers that have gained traction through downloads or 
social media mentions. These gatewatching routines not only serve to select topics for immediate coverage, but also to build a database of expertise with, for instance, names and contact details of academic experts and key scientific studies on topics that are expected to gain relevance in the future. In the case of COVID-19, the editors in the health department had long before identified, and in some cases established relationships with, experts in the fields of virology and epidemiology, in case of new or recurring viral outbreaks of, for instance, ebola or swine flu. As illustrated by the editor-in-chief:

\begin{abstract}
"We are like guides through the jungle where every tree is its own discipline with many branches and leaves. We are good at saying: tree number seven, fourth branch to the left, there is the expert on coronaviruses. [...] We know these experts and we fetch their expertise when science is making headlines, or when it should be." (Int_4_14012020) ${ }^{1}$
\end{abstract}

These routinized preparation and monitoring processes meant that the SMC's editorial team was able to identify the - at that time - mysterious lung disease in China, early on. "We actually knew about [the disease] long before it appeared in the media because we receive emails from ProMed, a distributor over which doctors from all over the world share their observations", explains an editor (Int_3_09012020). As will be illustrated next, the decision to cover the outbreak of COVID-19 was the result of a process in which the editorial team continuously reassessed its relative threat and relevance for coverage.

\title{
4.2 Continuous threat assessment
}

SMC editors normally apply a combination of journalistic, scientific, and organization-specific criteria to identify topics that could be relevant for coverage. One of the most important criteria is whether a topic is considered a "public issue", depending on the scope of affected people, its relevance for Germany and whether the topic is likely to feature in public debate or political decision-making. Secondly, the editors consider whether academic experts could shed new light on an issue, for instance by contextualizing new research or bringing new arguments into public debates. Every morning, the editors discuss their selections in the editorial meeting, where final decisions are made. The first mention of COVID-19 in the newsroom is made on 6 January over the in-office chat, where SMC Germany's editor-in-chief shares an article by the South China Morning Post about a mysterious lung disease in China:

\footnotetext{
"For now it's nothing to worry about, but I will put it on alert, this Wuhan pneumonia of unclear origin from China. Here is an article, so far they haven't found a pathogen but also no human-to-human transmission or infected hospital staff, so that sounds reassuring." [\#medizin_06012020]
}

The topic is discussed in the editorial meeting a few hours later, when the editor-in-chief suggests producing a "rapid fact sheet" with an overview of the key facts. The team decides against it because there are still too many unknowns, but

\footnotetext{
${ }^{1}$ The author has translated interview quotes, chat logs and publications from German into English.
} 
will keep the topic on high alert. During the next days, the mysterious lung disease in China is mentioned in the editorial meetings again, as it is increasingly garnering international media attention. The editors decide not to cover the disease yet, as it would be speculative to already let experts assess what it could be. On 9 January, the editor-in-chief shares an article by The New York Times about the lung disease in China, now thought to be a coronavirus. In the following editorial meetings, the staff notes that the virus features in many international and national headlines, especially after the first casualty has been reported in China. Meanwhile, the team is working on several other stories about new studies on gestational diabetes, cyanobacteria, stem cell mutations and social counteractions to climate change. The team is also closely following a federal debate on organ donation, which might have to be covered. The coronavirus is mentioned only a few times over the next weeks, for instance when the genome has been decoded, and when an editor shares an article from the German news agency dpa: "Today in dpa, it's said the pathogen in China is a Sars virus, it could be over and done with soon", along with the name of the interviewee, a German virologist (\#medizin_14012020).

The situation changes on 20 January. In the morning meeting, the editors discuss that the coronavirus' infection rate appears to be three times higher than previously assumed, and cases have been reported internationally. Despite other pressing issues, like a planned press briefing on e-cigarettes in Berlin and an expected WHO statement on Multiple Resistant Bacteria, it is decided that a health editor will draft a "rapid fact sheet" containing key points of the coronavirus (FN_20012020). It is published the following afternoon on January 21, entitled "Novel Coronavirus from Wuhan." Later that evening, multiple media outlets report that the coronavirus may be human-to-human transmissible. The editors discuss the developments over the in-office chat: "Not good if true," writes the editor-in-chief as he shares articles of reported cases in the U.S. and an interview with a virologist warning of an outbreak in Germany. "Should we quickly update our rapid fact sheet?" asks the deputy editor-in-chief.

The morning of 22 January, the editors decide that they will open a Google Doc to cooperate on updating the rapid fact sheet with the latest number of infections and threat analyses. At the same time, the health editors will prepare for the first case in Germany: "We're working on getting the virus assessed by experts. As of yet it is still far away from Germany, but the danger is there," says a health editor in the editorial meeting (FN_22012020). Over the next days, the editors share a large number of news articles about the quarantine measures put in place in Wuhan, and use the editorial meeting to discuss whether they will prepare an additional rapid reaction with expert commentary on this topic. Not everyone agrees with its timeliness: "Many TV shows are still calm, Wuhan is usually only the second or third story," says one editor. "I would wait until we hear from the WHO how they perceive the threat level" (FN_23012020). Nevertheless, a "rapid reaction" entitled "Quarantine Measures in China" with various expert assessments is sent out to journalists on 24 January.

\subsection{Rapid response requires digital cooperation}

Whereas the editorial team was able to manage the developments surrounding COVID-19 using their normal routines in the first three weeks of January, the 
rapidly evolving situation soon demanded editors to work evenings and weekends. Digital communication became increasingly important for sharing news articles and studies and discussions about the next steps to take.

In the morning of Saturday 25 January, the in-office chat rapidly fills with reports of the virus reaching Europe with three infected people in France, a highly accelerated infection rate and videos of chaotic circumstances in Chinese cities. In the "high alert" channel, the editor-in-chief and deputy write a message to the entire team, announcing that the health editors won't be joining a planned team excursion, so that there will be enough expertise available to summarize newly published papers and preprints, and gather expert statements (\#alert_redaktion_25012020). A "rapid reaction" is planned for Sunday, for which the editor-in-chief will try to contact the virologists, epidemiologists and clinical doctors that he knows personally to try and get statements quickly. Later, the deputy editor-in-chief describes the unfolding of the situation as follows:

\begin{abstract}
"We already noticed on Friday night that the situation was getting more dramatic [... S Since 20 January, the infection rate has been rising exponentially [...] It was clear to us that we have to do something, even if the virologists currently don't think the virus will be as lethal as Sars [...] We decided to establish a "Corona Task Force" consisting of the three health editors, the editor-in-chief and me [...] We basically had no weekend but it resulted in a Google Doc that we could all work in simultaneously and which we sent as a rapid reaction on Sunday." (Int_10_27012020)
\end{abstract}

The following day, Monday 27 January, the editors attending the editorial meeting note that last weekend's publications about the coronavirus have been picked up by dozens of news media. Because SMC Germany allows journalists to use its content without source referral, the only way to measure impact is to actively search for copied expert statements: a practice that has become routine after each published story. The members of the "Corona Task Force" aren't present to hear about this success, however, as they are in a separate office to prepare a new publication aimed to be sent out the same day. The deputy editor-in-chief discloses the plan: "Although I don't see a threat for Europe yet, it's also important to de-escalate, so we really should try to get something out still today," he says. "Our goal is to work with this Google Doc again and either create a fact sheet with an overview of the latest numbers or a rapid reaction that includes new expert statements [...] Because so much is happening, I'm thinking the latter could be more useful for the colleagues." (Int_10_27102020)

During the course of the day, the health editors receive multiple calls from journalists asking for interviews about the current situation of the virus. Some of the journalists appear to have been redirected from the Robert Koch Institute (RKI) - the state agency for disease control. In every call, the editor explains that the SMC are not experts themselves but instead gather scientific findings and assessments from experts. The journalists are welcome to try and contact their sources, but can also directly use the expert statements published on the SMC website (FN_27012020). The discussions emerging in the newsroom signal that incoming calls and interview requests are not a usual occurrence. When asked, the editor-in-chief explains it's likely due to an overload of journalistic inquiries to the RKI, who are themselves dealing with a higher workload. "So then the question is, 
can someone else talk? That's either us, or the experts out there. There are perhaps five corona experts here in Germany, and they can't talk to the press all day, that just doesn't work" (Int_13_29012020).

\subsection{Crisis defines knowledge broker role}

The incoming calls from journalists, the referrals from the state agency for disease control, and the success of the previous publications already seemed to signal that the SMC was starting to be considered a hub of expertise on the novel coronavirus. As the virus drew nearer to Germany, the editorial team itself was increasingly strengthened in its mission to swiftly react to the newest developments and provide journalists with the latest assessments of the epidemic.

In the early morning of 28 January at 3:05 am, the deputy editor-in-chief sends out the following message in the chat: "First case in Germany!" with a link to an article of the Süddeutsche newspaper reporting a confirmed COVID-19 case in Bavaria. Only a few hours later, at 7:40 am, the deputy editor-in-chief has finalized the "rapid fact sheet" the Corona Task Force had been working on, and has sent it out to accredited journalists. The teaser reads: "Dear colleagues, the first case in Germany has been confirmed just now, more cases are to be expected. In this rapid fact sheet we put together relevant facts, questions and resources with which you can follow the developments of this outbreak." In the editorial meeting some hours later, the editors discuss the first German case. Because the information is so new, there aren't many news reports yet. The plan is to send out a rapid reaction with expert statements on the German case as soon as possible: "The topic is virulent, so the quicker the better. It will be good for our name if we act fast, and besides, this will be interesting to everyone, not just journalists," says one of the editors (FN_28012020). In the meantime, the in-office chat is used to share news articles and preprint studies ready to be assessed by the experts the editorial team is contacting. In the early evening, a rapid reaction entitled "First Case in Germany" containing expert statements about human-to-human infection and threat assessments for Germany is sent out to journalists.

The next day, 29 January, the editorial meeting is cut short on request of the editor-in-chief, to ensure that the Corona Task Force can quickly return to work. Again, the SMC's publications of the previous days seem to have been taken over frequently in German news media. The editor-in-chief tells the editors:

\footnotetext{
"The coronavirus is dominating everything [...] A key question is whether the virus is transmittable without symptoms, that is very unclear. We cannot influence the general flow of media, but the scientific side, that's where we can now make a difference. We're receiving new findings around the clock, that means that we also have to inform the colleagues about what preprint studies are. And somehow we have to design a functioning flow of information, similar to the fact sheets that we are updating continuously." (FN_29012020)
}

Later, the deputy editor-in-chief explains that the SMC's primary focus for the next days will be to keep their publications up to date. "We've been discussing whether we need a different format for this, so that in repeated cycles, [journalist] colleagues can look up current scientific assessments of the situation" (Int_12_29012020). It is 
decided that there will be two Google Docs, one for the editors to internally validate and classify all collected papers, and one with a teaser and a structured, up to date list of information and resources that will be shared externally with all accredited journalists. This new format, called "annotated publication list", will include scientific publications, as well as preprint studies on COVID-19. Considering that the SMC normally does not use non-peer-reviewed research in its publications for journalists, the editorial staff decides to design a classification system to convey the perceived quality and relevance of all listed papers, including preprints:

*** Highly relevant scientific publications with important findings

** Publication providing background and illustration to well-founded hypotheses

* Unclear quality or unconfirmed hypotheses, publications without independent review, which should be treated with caution for the time being

!!! Publications that have not yet been peer-reviewed and that inexperienced readers should not use as a guide to clinical practice or health-related behaviour.

When asked about the decision to choose this format, the deputy editor-in-chief explains that the team was trying to find an easier way to keep journalists updated with the latest information:

\footnotetext{
"This is the difference: we're not an agency or press office for science. We are a science newsroom that wants to share information with others, so that they can share it again in their work. It is a service from journalists to journalists [...] We convey expertise. Doing that in this crisis situation is exactly what we're there for [...] This is our mission." (Int_12_29012020)
}

That week, the SMC team sends out the annotated publication list, a rapid reaction with expert statements on the transmissibility of the coronavirus and an invitation to a press briefing held in Berlin where the SMC has invited virologists to talk about the potential dangers of the novel coronavirus.

\subsection{Adapting output to meet journalists' needs}

Over the next three months, COVID-19 continues to dominate the work of the SMC newsroom. A simple content analysis shows that between January and May 2020, journalists accredited by SMC Germany received a total of 115 publications, of which 91 concerned the novel coronavirus. To put this topic homogeneity into perspective, in the time period from September to December 2019, SMC Germany sent out a total of 101 publications addressing 50 different topics, ranging from bioenergy and electric cars to artificial intelligence and bioengineered embryos. As can be seen in Table 1, the most common format sent out by the SMC during the first four months of 2020 is the rapid reaction, in which experts from various scientific fields answer editors' questions about the pandemic's latest developments, e.g. possible measures to halt its spread in Europe, the likelihood of immunity after recovery from COVID-19 or the consequences of the pandemic for agriculture and food logistics. 
Table 1. Publication formats used by SMC Germany between 1 January and 30 April 2020. * $=$ new format used in response to COVID-19 pandemic.

\begin{tabular}{|l|l|c|}
\hline Publication format & Description & \# \\
\hline Research in Context & $\begin{array}{l}\text { Summaries of scientific papers including expert state- } \\
\text { ments on the content, quality and relevance of the } \\
\text { findings. }\end{array}$ & 16 \\
\hline Rapid Reaction & $\begin{array}{l}\text { Expert statements on acute developments in science, } \\
\text { society, politics that are generating media attention. }\end{array}$ & 48 \\
\hline Factsheet & $\begin{array}{l}\text { Background information on complex, long-term or re- } \\
\text { curring scientific topics. Includes expert statements } \\
\text { and scientific resources. }\end{array}$ & 3 \\
\hline Rapid Factsheet & $\begin{array}{l}\text { Background information on complex scientific topics } \\
\text { of acute public relevance. Includes expert statements } \\
\text { and scientific resources. }\end{array}$ & 3 \\
\hline Press Briefing & $\begin{array}{l}\text { Moderated, physical press conference with scientific } \\
\text { experts commenting on typically long-term or recur- } \\
\text { ring scientific topics. }\end{array}$ & 4 \\
\hline Virtual Press Briefing * & $\begin{array}{l}\text { Moderated, digital press conference in webinar format } \\
\text { with scientific experts commenting on topics of acute } \\
\text { public relevance. }\end{array}$ & 12 \\
\hline Annotated Publication List * & $\begin{array}{l}\text { Structured list of scientific publications and preprints } \\
\text { on topics of acute public relevance. A rating system } \\
\text { conveys their perceived soundness and tenability. }\end{array}$ & 2 \\
\hline Corona Daily Update * & $\begin{array}{l}\text { Daily renewed publication listing the latest quantitat- } \\
\text { ive developments of COVID-19 in Germany and bey- } \\
\text { ond, including visual data representations. }\end{array}$ & 27 \\
\hline
\end{tabular}

Interestingly, several new formats are introduced as well. On 6 March, SMC Germany holds its first ever virtual press briefing, entitled "Vaccine against the novel coronavirus - which hurdles are to be conquered?." The 50-minute press briefing hosts three experts, two virologists and a biochemist, and gives journalists the opportunity to send in questions both before and during the event. Until the end of April, the SMC hosts 7 more virtual press briefings, on topics like hospital preparations in Germany, the interactions of COVID-19 with the heart and possible consequences of the pandemic for climate change and climate politics. On 20 March, SMC Germany introduces another format: the "Corona Daily Report". The teaser reads: "With this report we're making available the latest, relevant numbers and developments of the corona crisis in Germany. Not only do we deliver the bare numbers, like the current SARS-CoV-2 rate, but we also arrange them and their development over time. In this way, it is possible to see in one glance what's going on in Germany and beyond." It includes a link to a PDF-file comprising the current infection rate in Germany, the doubling time in Germany in comparison to other countries, and a graph of the worldwide spread of the COVID-19 pandemic. Until 30 April, the SMC continues to send out its Corona Daily Reports every working day, usually with a different focus such as the situation in neighbouring countries, or mathematical strategies for calculating the doubling time of infected cases. 
[Bucchi, 1996; Reynolds and Seeger, 2005]. Scientific expertise and certain knowledge rapidly become desired commodities for journalists and the public alike - pushing some communicative actors forward and others backward [Garrett, 2001; Robinson and Newstetter, 2003]. An intermediary organization like the Science Media Center with close ties to both scientists and journalists is then aptly positioned to fulfill a central role in science communication. The goal of this paper was to show how SMC Germany responded to the outbreak of COVID-19 in the first phase of the pandemic, when its threat was still unclear and scientific knowledge about the virus scarce. In particular, the ethnographic data gathered during the fieldstay in January 2020 - including interviews, field notes, publications and chat logs - has provided unique, empirical insights into how SMC Germany recognized the outbreak as a crisis situation, subsequently adapted its newsroom practices and understood its own role and mission in COVID-19 communication. The analysis resulted in five core findings, which will each be shortly explored:

(1) SMC Germany's anticipatory routines helped it prepare for a swift response. Especially the gatewatching and expertise gathering routines helped the team to identify the outbreak as a potential topic early on, and swiftly respond to its later developments. Here, the SMC holds a special advantage over regular newsrooms: since it is the organization's explicit mission to be vigilant at all times and react "when science hits the headlines", the editorial team is given the time and freedom to use their specialized knowledge to not only define topics expected to become relevant in the future, but also to maintain long-standing relationships with scientists. Further aiding the anticipatory routines is the "SMC Lab" - the organization's R\&D department that has designed various tools to help the editorial team specifically search for key themes in news media, scientific journals and preprint repositories. This meant that even when the COVID-19 had not yet reached Europe, the editorial team had ample opportunity to gather background information, scientific publications and a list of experts to contact in case the virus would reach Germany.

(2) The right moment for coverage was decided through a process of continuous relevance assessment, in which a gradual recognition of the outbreak as a public risk was weighed against the lack of scientific knowledge. This assessment took place in editorial meetings and in-office chats, where the latest insights on the virus were weighed against organizational topic selection criteria. The uncertainty surrounding the virus and its distance from Germany in the first weeks of January, in combination with pressing topics in German politics and stories that were already underway, meant that the virus as a developing story did not hold up to these criteria at first. This assessment gradually changed, driven by both, the increased media attention from high quality international and German news media, and the exponentially rising international infection rates. In particular, however, the virus' entry into Europe turned COVID-19 into an undeniable "public issue" for the editorial staff, which underscores the importance of locality and proximity in topic selection.

(3) The editorial staff developed new, digital communication strategies in response to both the quick spread and changing insights about the virus, and SMC Germany's own desire to rapidly provide journalists with expertise. These strategies included a shared knowledge base using Google Docs, as opposed to the regular, server-based documentation routines, as well as an increased use of in-office chat channels to 
internally share news stories, preprints as well as personal assessments of the developing COVID-19 outbreak.

(4) The outbreak of COVID-19 further accentuated SMC's knowledge broker role for itself as well as other actors in science communication. Though the work of SMC Germany to identify knowledge needs, gather expertise and translate this for journalistic use can be characterised as that of a knowledge broker in regular times, the acute demands posed by the early phase of the outbreak further highlighted this role. The incoming calls from journalists and referrals from the state authority for infectious disease signal a heightened visibility and relevance of SMC Germany as a base for knowledge and expertise. At the same time, the early phase of the COVID-19 outbreak also posed an opportunity for SMC Germany to reflect on its mission to provide journalists with scientific expertise, and to strengthen its role in science communication.

As a result, (5) SMC Germany adapted its output formats to fulfill its knowledge broker role during the outbreak. In an effort to display the quickly changing knowledge situation and respond to the needs of accredited journalists, the editorial team devised several new publication formats including the annotated publication list, the virtual press briefing and the corona daily report. In addition, due to the lack of peer-reviewed research on COVID-19 in the initial phase of the outbreak, SMC Germany had to adapt its selection criteria for scientific resources. Though preprints are not normally used for purposes other than topic monitoring, the editorial team became increasingly dependent on preprint repositories, which became a main source of initial research data on COVID-19. The design of a newly designed ranking system conveying the perceived quality and relevance of COVID-19 related (pre-print) studies, and its subsequent inclusion in publications for journalists, helped SMC Germany to keep fulfilling its knowledge broker role despite the volatile knowledge situation.

Taken together, these ethnographic findings not only illustrate SMC Germany's response to the COVID-19 outbreak, they also show its highlighted role as a knowledge broker for journalism in uncertain times. It is well possible that the pandemic has strengthened the SMC's position in German science communication, which calls for further investigation. As mentioned earlier, the newsroom ethnography central to this paper did not start out as an investigation of editorial responses to the COVID-19 outbreak, which developed when the month-long fieldstay was already underway. The findings, therefore, reflect ad hoc adaptations in response to COVID-19 rather than sustainable, long-term changes. Despite these limitations, the strength of this paper lies in the in-depth observations of that initial, volatile period of the COVID-19 crisis, during which the editorial staff had to grapple with a sense of looming urgency on the one hand, and scientific unknowns on the other. Though many questions concerning COVID-19 communication still need to be answered, this paper has provided a first empirical account of the editorial response of a potentially highly influential knowledge broker in science communication. The sustainability of SMC Germany's editorial adaptations, as well as the development of its editorial practices, roles and relationships in the aftermath of COVID-19, will provide excellent topics for further investigation. In addition, future research could compare responses of SMCs internationally or explore their impact on the issue framing and expert visibility in COVID-19 in news coverage. 
Acknowledgments This publication is based on a project financed by the German Federal Ministry of Education and Research (BMBF) under the funding code 01 PU17O18D. Solely the author is responsible for its content.

References

Barzilai-Nahon, K. (2008). ‘Toward a theory of network gatekeeping: a framework for exploring information control'. Journal of the American Society for Information Science and Technology 59 (9), pp. 1493-1512. https://doi.org/10.1002/asi.20857.

Bielak, A. T., Campbell, A., Pope, S., Schaefer, K. and Shaxson, L. (2008). 'From science communication to knowledge brokering: the shift from 'science push' to 'policy pull". In: Communicating science in social contexts: new models, new practices. Ed. by D. Cheng, M. Claessens, T. Gascoigne, J. Metcalfe, B. Schiele and S. Shunke. Dordrecht, The Netherlands: Springer, pp. 201-226. https://doi.org/10.1007/978-1-4020-8598-7_12.

Boczkowski, P. J. (2004). Digitizing the news. Innovation in online newspapers. Cambridge, MA, U.S.A.: The MIT Press. https://doi.org/10.7551/mitpress/2435.001.0001.

British Council of the Royal Society (1986). 'Public Understanding of Science: The Royal Society Reports'. Science, Technology, E Human Values 11 (3), pp. 53-60. https://doi.org/10.1177/016224398601100306.

Bruns, A. (2005). Gatewatching: collaborative online news production. New York, NY, U.S.A.: Peter Lang.

Bucchi, M. (1996). 'When scientists turn to the public: alternative routes in science communication'. Public Understanding of Science 5 (4), pp. 375-394. https://doi.org/10.1088/0963-6625/5/4/005.

Callaway, E. (2013). 'Science media: centre of attention'. Nature 499 (7457), pp. 142-144. https://doi.org/10.1038/499142a.

Charmaz, K. (2006). Constructing grounded theory: a practical guide through qualitative analysis. London, U.K.: Sage Publications.

- (2014). Constructing grounded theory: a practical guide through qualitative analysis. 2nd ed. London, U.K.: Sage Publications.

Cotter, C. (2010). News talk. Investigating the language of journalism. Cambridge, U.K.: Cambridge University Press. https://doi.org/10.1017/cbo9780511811975.

Cottle, S. (2000). 'New(s) times: towards a 'second wave' of news ethnography'. Communications 25 (1), pp. 19-41. https://doi.org/10.1515/comm.2000.25.1.19.

Donsbach, W. (2014). 'Journalism as the new knowledge profession and consequences for journalism education'. Journalism: Theory, Practice $\mathcal{E}$ Criticism 15 (6), pp. 661-677. https://doi .org/10.1177/1464884913491347.

Esser, F. (1998). 'Editorial structures and work principles in British and German newsrooms'. European Journal of Communication 13 (3), pp. 375-405. https://doi.org/10.1177/0267323198013003004.

Fishman, M. (1980). Manuctaring the news. Austin, U.S.A.: University of Texas Press.

Fox, F. (2009). 'Science communication and ethics - trying to get it right: the science media centre - a case study'. In: Communicating biological sciences. Ethical and metaphorical dimensions. Ed. by B. Nerlich, R. Elliott and B. Larson. Surrey, U.K.: Ashgate, pp. 109-128.

Gans, H. J. (1979). Deciding what's news. A study of CBS Evening News, NBC Nightly News, Newsweek and Time. 1st ed. New York, NY, U.S.A.: Pantheon Books. 
Garrett, L. (2001). 'Understanding media's response to epidemics'. Public Health Reports 116, pp. 87-91. https://doi.org/10.1016/s0033-3549(04)50149-8.

Gesualdo, N., Weber, M. S. and Yanovitzky, I. (2020). 'Journalists as knowledge brokers'. Journalism Studies 21 (1), pp. 127-143.

https://doi.org/10.1080/1461670x.2019.1632734.

Golding, P. and Elliot, P. (1979). Making the news. London, U.K. and New York, NY, U.S.A.: Longman.

Halbach, M. (Forthcoming). 'A quantitative content analysis of SMC Germany publications in the German press'. Master thesis. Dortmund, Germany: Institute for Journalism, Technische Universität Dortmund.

Hannerz, U. (2004). Foreign news: exploring the world of foreign correspondents. Chicago, IL, U.S.A.: University of Chicago Press.

Haran, J. (2012). 'Campaigns and coalitions: governance by media'. In: The sciences' media connection - public communication and its repercussions. Sociology of the sciences yearbook. Ed. by S. Rödder, M. Franzen and P. Weingart. Dordrecht, The Netherlands: Springer, pp. 241-256. https://doi.org/10.1007/978-94-007-2085-5_12.

Hargadon, A. B. (1998). 'Firms as knowledge brokers: lessons in pursuing continuous innovation'. California Management Review 40 (3), pp. 209-227. https://doi.org/10.2307/41165951.

- (2002). 'Brokering knowledge: linking learning and innovation'. Research in Organizational Behavior 24, pp. 41-85. https://doi.org/10.1016/s0191-3085(02) 24003-4.

Hettwer, H., Rödder, S. and Zotta, F. (2012). 'Das britische Science Media Centre und was wir davon lernen können'. WPK Quarterly 1 (1), pp. 16-18.

URL: https://www . wpk. org/quarterly/einzelartikel/das-britische-scien ce-media-centre- (smc)-und-was-wir-davon-lernen-koennen.html.

Hunter, A., Murphy, K., Grealish, A., Casey, D. and Keady, J. (2011). 'Navigating the grounded theory terrain. Part 1'. Nurse Researcher 18 (4), pp. 6-10. https://doi.org/10.7748/nr2011.07.18.4.6.c8636.

Johri, A. (2008). 'Boundary spanning knowledge broker: an emerging role in global engineering firms'. In: $200838^{\text {th }}$ Annual Frontiers in Education Conference (Saratoga Springs, NY, U.S.A. 22nd-25th October 2008). IEEE. https://doi.org/10.1109/fie.2008.4720407.

Kunelius, R. and Ruusunoksa, L. (2008). 'Mapping professional imagination'. Journalism Studies 9 (5), pp. 662-678. https://doi.org/10.1080/14616700802207581.

Lave, J. and Wenger, E. (1991). Situated learning: legitimate peripheral participation. Cambridge, U.K.: Cambridge University Press.

Lomas, J. (2007). 'The in-between world of knowledge brokering'. BMJ 334 (7585), pp. 129-132. https://doi.org/10.1136/bmj .39038.593380.ae.

Luhmann, N. (1999). Funktionen und Folgen formaler Organisation. Original publication year (1964). Berlin, Germany: Duncker \& Humblot.

McKie, R. (2nd June 2002). 'Lobby group 'led GM thriller critics". The Guardian. URL: https://www. theguardian.com/science/2002/jun/02/gm.observerscie ncepages.

Meyer, M. (2010). 'The rise of the knowledge broker'. Science Communication 32 (1), pp. 118-127. https://doi.org/10.1177/1075547009359797.

Neyland, D. (2008). Organizational ethnography. London, U.K.: Sage Publications. https://doi.org/10.4135/9781849209526. 
Nisbet, M. C. and Fahy, D. (2015). 'The need for knowledge-based journalism in politicized science debates'. The Annals of the American Academy of Political and Social Science 658 (1), pp. 223-234. https://doi.org/10.1177/0002716214559887.

Paterson, C. and Domingo, D. (2008). Making online news: the ethnography of new media production. Oxford, U.K.: Peter Lang.

- (2011). Making online news - volume 2: newsroom ethnographies in the second decade of journalism. Oxford, U.K.: Peter Lang.

Patterson, T. (2013). Informing the news: the need for knowledge-based journalism. New York, NY, U.S.A.: Vintage Books.

Pawlowski, S. D., Robey, D. and Raven, A. (2000). 'Supporting shared information systems: boundary objects, communities and brokering'. In: Proceedings of the twenty first international conference on information systems. Atlanta, GA, U.S.A.: Association for Information Systems, pp. 329-338. URL: https://aisel.aisnet.org/icis2000/30/.

Pedelty, M. (1995). War stories: the culture of foreign correspondents. London, U.K.: Routledge.

Pielke, R. A. J. (2007). The Honest Broker. Cambridge, U.S.A.: Cambridge University Press.

Reynolds, B. and Seeger, M. W. (2005). 'Crisis and emergency risk communication as an integrative model'. Journal of Health Communication 10 (1), pp. 43-55. https://doi.org/10.1080/10810730590904571.

Robinson, S. J. and Newstetter, W. C. (2003). 'Uncertain science and certain deadlines: CDC responses to the media during the Anthrax attacks of 2001'. Journal of Health Communication 8 (sup1), pp. 17-34. https://doi.org/10.1080/713851980.

Rödder, S. (2012). 'The Ambivalence of Visible Scientists'. In: The Sciences' Media Connection - Public Communication and its Repercussions. Ed. by S. Rödder, M. Franzen and P. Weingart. Vol. 28. Sociology of the Sciences Yearbook. Dordrecht, The Netherlands: Springer, pp. 155-177. https://doi.org/10.1007/978-94-007-2085-5_8.

- (2014). ‘Qualität im Gesundheitsjournalismus - welche Rolle kann ein Science Media Centre spielen?' In: Qualität im Gesundheitsjournalismus. Ed. by V. Lilienthal, D. Reineck and T. Schnedler. Wiesbaden, Germany: Springer Fachmedien, pp. 399-412. https://doi .org/10.1007/978-3-658-02427-7_23.

- (2015). 'Science media centres and public policy'. Science and Public Policy 42 (3), pp. 387-400. https://doi.org/10.1093/scipol/scu057.

- (2017). 'Organisationstheoretische Perspektiven auf die Wissenschaftskommunikation'. [Perspectives from organisational theory on science communication]. In: Forschungsfeld Wissenschaftskommunikation. [The field of science communication]. Ed. by H. Bonfadelli, B. Fähnrich, C. Lüthje, J. Milde, M. Rhomberg and M. S. Schäfer. Wiesbaden, Germany: Springer Fachmedien, pp. 63-81.

https://doi.org/10.1007/978-3-658-12898-2_4.

- (2020). ‘Organisation matters: towards an organisational sociology of science communication'. Journal of Communication Management 24 (3), pp. 169-188. https://doi.org/10.1108/jcom-06-2019-0093.

Satterfield, D., Burd, C., Valdez, L., Hosey, G. and Shield, J. E. (2002). 'The "in-between people": participation of community health representatives in diabetes prevention and care in American Indian and Alaska native communities'. Health Promotion Practice 3 (2), pp. 166-175. https://doi.org/10.1177/152483990200300212. 
Schlesinger, P. (1978). Putting 'reality' together: BBC News. London, U.K.: Constable.

Schultz, I. (2007). 'The journalistic gut feeling'. Journalism Practice 1 (2), pp. 190-207. https://doi.org/10.1080/17512780701275507.

Science Media Center Germany (2020). How we finance ourselves. URL: https://www.sciencemediacenter.de/en/smc/financing/.

Science Media Centre U.K. (2020). Funding. URL: https://www. sciencemediacentre.org/about-us/funding/.

Shinn, T. and Joerges, B. (2002). 'The transverse science and technology culture: dynamics and roles of research-technology'. Social Science Information 41 (2), pp. 207-251. https://doi.org/10.1177/0539018402041002003.

Sverrisson, Á. (2001). 'Translation networks, knowledge brokers and novelty construction: pragmatic environmentalism in Sweden'. Acta Sociologica 44 (4), pp. 313-327. https://doi.org/10.1080/00016990152696402.

Tanaka, M. (2015). 'Agenda building intervention of socio-scientific issues: a science media centre of Japan perspective'. In: Lessons from Fukushima. Ed. by Y. Fujigaki. Cham, Switzerland: Springer International Publishing, pp. 27-55. https://doi.org/10.1007/978-3-319-15353-7_3.

Tuchman, G. (1973). 'Making news by doing work: routinizing the unexpected'. American Journal of Sociology 79 (1), pp. 110-131. https://doi.org/10.1086/225510.

- (1978). Making news: A study in the construction of reality. New York, U.S.A.: Free Press.

Wachelder, J. (2003). 'Democratizing science: various routes and visions of Dutch science shops'. Science, Technology, E Human Values 28 (2), pp. 244-273. https://doi.org/10.1177/0162243902250906.

Ward, V., House, A. and Hamer, S. (2009). 'Knowledge brokering: the missing link in the evidence to action chain?' Evidence E Policy: A Journal of Research, Debate and Practice 5 (3), pp. 267-279. https: //doi .org/10.1332/174426409x463811.

Williams, A. and Gajevic, S. (2013). 'Selling science? Source struggles, public relations and U.K. press coverage of animal human hybrid embryos'. Journalism Studies 14 (4), pp. 507-522. https://doi.org/10.1080/1461670x.2012.718576.

Ybema, S., Yanow, D., H., W. and Kamsteeg, F. (2009). Organizational ethnography. Studying the complexities of everyday life. London, U.K.: Sage Publications.

Author

Irene G. B. Broer is a doctoral researcher at the Leibniz Institute for Media Research I Hans Bredow Institute located in Hamburg, Germany. Using qualitative methods, her research focuses on new intermediaries in science communication and Science Media Centers in particular. E-mail: i.broer@leibniz-hbi.de.

\section{How to cite}

Broer, I. (2020). 'Rapid reaction: ethnographic insights into the Science Media Center and its response to the COVID-19 outbreak'. JCOM 19 (05), A08. https://doi.org/10.22323/2.19050208. 